\title{
Climate change impacts and potential benefits of heat-tolerant maize in South Asia
}

\author{
Kindie Tesfaye $^{1} \cdot$ P. H. Zaidi ${ }^{2}$ Sika Gbegbelegbe ${ }^{3} \cdot$ Christian Boeber $^{4}$. \\ Dil Bahadur Rahut ${ }^{5} \cdot$ Fite Getaneh $^{1} \cdot$ K. Seetharam ${ }^{2}$ - Olaf Erenstein ${ }^{5}$. Clare Stirling ${ }^{6}$
}

Received: 28 October 2015 / Accepted: 6 September 2016/Published online: 14 September 2016

(C) The Author(s) 2016. This article is published with open access at Springerlink.com

\begin{abstract}
Maize is grown by millions of smallholder farmers in South Asia (SA) under diverse environments. The crop is grown in different seasons in a year with varying exposure to weather extremes, including high temperatures at critical growth stages which are expected to increase with climate change. This study assesses the impact of current and future heat stress on maize and the benefit of heat-tolerant varieties in $\mathrm{SA}$. Annual mean maximum temperatures may increase by $1.4-1.8^{\circ} \mathrm{C}$ in 2030 and $2.1-2.6^{\circ} \mathrm{C}$ in 2050 , with large monthly, seasonal, and spatial variations across SA. The extent of heat stressed areas in SA could increase by up to $12 \%$ in 2030 and $21 \%$ in 2050 relative to the baseline. The impact of heat stress and the benefit from heat-tolerant varieties vary with the level of temperature increase and planting season. At a regional scale, climate change would reduce rainfed maize yield by
\end{abstract}

Electronic supplementary material The online version of this article (doi:10.1007/s00704-016-1931-6) contains supplementary material, which is available to authorized users.

Kindie Tesfaye

K.tesfayefantaye@ cgiar.org

1 International Maize and Wheat Improvement Center (CIMMYT), Addis Ababa, Ethiopia

2 International Maize and Wheat Improvement Center (CIMMYT), Hyderabad, India

3 International Institute of Tropical Agriculture (IITA), Lilongwe, Malawi

4 International Maize and Wheat Improvement Center (CIMMYT), New Delhi, India

5 International Maize and Wheat Improvement Center (CIMMYT), El Batan, Mexico

6 International Maize and Wheat Improvement Center (CIMMYT), London, UK an average of 3.3-6.4\% in 2030 and 5.2-12.2\% in 2050 and irrigated yield by $3-8 \%$ in 2030 and $5-14 \%$ in 2050 if current varieties were grown under the future climate. Under projected climate, heat-tolerant varieties could minimize yield loss (relative to current maize varieties) by up to 36 and $93 \%$ in 2030 and 33 and $86 \%$ in 2050 under rainfed and irrigated conditions, respectively. Heat-tolerant maize varieties, therefore, have the potential to shield maize farmers from severe yield loss due to heat stress and help them adapt to climate change impacts.

Keywords Climate change $\cdot$ Heat stress $\cdot$ Heat stress tolerance $\cdot$ Maize $\cdot$ South Asia

\section{Introduction}

Climate change poses a formidable threat to the sustainable development of South Asia (SA), as the region is vulnerable to the impacts of climate change due to high population density, poverty, and lack of resources for adaptation (Ahmed and Suphachalasai 2014). Despite rapid urbanization, the majority of the SA population is still rural and dependent on agriculture for their livelihoods (Hijioka et al. 2014) and will remain vulnerable to climate shocks for the foreseeable future.

Warming has occurred across most of South Asia over the twentieth century and into the twenty-first century with more frequent incidences of temperature extremes (Lal 2005; Lal 2011; Hijioka et al. 2014). Records indicate a decrease in the number of cold days and nights and an increase in the number of warm days and nights across most of Asia since 1950; and heat wave frequency has increased since the middle of the twentieth century in large parts of Asia (Hijioka et al. 2014).

Many studies suggest that the frequency of high daytime and night time temperatures will increase in the near future, 
and this will present a tremendous challenge to global food production and food security (Lobell et al. 2011a; Cairns et al. 2012; Hijioka et al. 2014). Extreme heat stress during the crop reproductive period can be critical for crop productivity, and hence projected changes in the frequency and severity of extreme climatic events are expected to negatively impact crop yields and global food production (Knox et al. 2012; Gourdji et al. 2013; Deryng et al. 2014). Each rise in mean temperature by $1{ }^{\circ} \mathrm{C}$ is predicted to cause huge yield losses in India, and farmers are projected to lose up to US\$20 billion each year (FAO 2008; Swaminathan and Kesavan 2012).

Maize production has been growing rapidly in SA over the last decades with an annual harvested area reaching 12 million ha recently (FAOSTAT 2013). The growth is in response to a surge in regional maize demand, driven by economic growth, changing diets, and the rapidly growing poultry sector, where maize constitutes about $65 \%$ of the poultry ration (Shiferaw et al. 2011; Hellin et al. 2015). Maize is now grown by millions of smallholder farmers in the region almost all year round mostly under sub-tropical rainfed lowland conditions.

Maize is particularly vulnerable to heat stress during the reproductive stage (Rattalino Edreira et al. 2011; Cairns et al. 2012; Mayer et al. 2014; Rezaei et al. 2015), and it is reported that each degree increase in a day where the temperature exceeds $30{ }^{\circ} \mathrm{C}$ reduces the final yield of maize by $1 \%$ under favorable growing conditions and by $1.7 \%$ under drought-stressed conditions (Lobell et al. 2011b). Most of the sub-tropical maize-growing areas in SA are highly vulnerable to high temperature stress, particularly during the premonsoon season when maize is prone to severe heat stress during anthesis and early grain-filling stages (Prasanna 2011).

Development and effective targeting of heat-tolerant maize varieties is needed to improve the resilience of maize production under heat-stressed conditions. Currently, there is little quantitative information to illustrate the potential benefits of heat-tolerant maize varieties across SA to inform research and investment decisions. This is partly due to a lack of ex-ante analytical tools that allow for exploration under future climatic conditions. Recently, however, crop models have been used for the comparison of various scenarios and strategies, such as quantifying the potential benefits of incorporating drought tolerance, heat tolerance, and other yield-enhancing traits into commonly grown cultivars of different crops under climate change (Rinaldi et al. 2007; Singh et al. 2014a; Singh et al. 2014b; Singh et al. 2014c; Kadiyala et al. 2015). The present paper contributes to the literature with the case of heat-tolerant maize in SA. The objectives of this study were to assess the effects of current and future heat stress on maize in SA in order to (a) estimate the impacts of climate change on maize yield and (b) quantify the benefits of heat-tolerant maize varieties at different spatial and temporal scales in the region using cropmodeling approaches.

\section{Methodology}

\subsection{Description of the study region}

The study was conducted in the SA region which includes seven countries: Afghanistan, Bangladesh, Bhutan, India, Nepal, Pakistan, and Sri Lanka. The climate of the region varies considerably from tropical in the south to temperate and alpine in the north and is mainly influenced by latitude, altitude, and the seasonal impact of the monsoon. Although planting seasons can vary, most areas plant maize under rainfed conditions from June onward for the monsoon season and/or under irrigated conditions around October and/or March. Despite high rates of economic growth and steady progress in poverty reduction in recent years, nearly half of the world's poor live in the region and comprise nearly a third of the 1.5 billion inhabitants (Ahmed and Suphachalasai 2014). Moreover, climate change is emerging as a significant risk to sustainment of economic development and growth in the region.

\subsection{Identification of current and future heat stress hotspots}

The heat stress hotspots were identified after a geospatial analysis of baseline 1950-2000 (2000) and future, 2020-2049 (2030), and 2040-2069 (2050) climate datasets (monthly maximum and minimum temperatures) using the ArcGIS spatial analyst tool. The baseline climate data were obtained from the WorldClim database (Hijmans et al. 2005; http://www. worldclim.org/), while the projected downscaled climate data for Commonwealth Scientific and Industrial Research Organisation (CSIRO-Mk3.6) and Model for Interdisciplinary Research on Climate (MIROC-ESM-CHEM) general circulation models (GCMs) for the medium representative concentration pathway (RCP6.0) scenario (van Vuuren et al. 2011; van Vuuren and Carter 2014) were obtained from the Climate Change Agriculture and Food Security (CCAFS) climate data portal (CCAFS 2014; http://www.ccafs-climate.org/). Discernable differences between the various emission scenarios only become apparent after the mid-century (van Vuuren and Carter 2014), and hence, only RCP6.0 was used for this study.

\subsection{Model description, calibration, and evaluation}

The cropping system model (CSM) used to simulate maize growth was Crop Estimation through Resource and Environment Synthesis, CERES-Maize (Jones and Kiniry 1986), which is embedded in the Decision Support System for Agrotechnology Transfer, DSSAT v4.5 (Jones et al. 2003; Hoogenboom et al. 2010). CERES-Maize is a process-based, management-oriented model that utilizes water, carbon, nitrogen, and energy balance principles to simulate the growth and development of maize plants within an 
agricultural system. The model runs with a daily time step and simulates crop growth, development, and yield of specific cultivars based on the effects of weather, soil characteristics, and crop-management practices (Jones et al. 2003).

The CERES-Maize model was calibrated for four hybrid maize varieties currently grown in South Asia (31Y45, 900MG, DKC9108, HTMH540), using yield and phenology (2010-2013) and crop growth (2013) data collected from Hyderabad (17.62858 N, 78.55928 E) research station. The CERES-Maize model requires six genetic coefficients which govern the life cycle and reproductive growth of maize cultivars (Table 1). A stepwise iterative calibration procedure was followed whereby genetic coefficients which determine anthesis and physiological maturity dates (P1, P2, and P5) were adjusted in the first stage of the process, followed by those coefficients which influence yield (G2 and G3). Rooting profile (RGF) and soil fertility factor (SPLF) were also adjusted together with G2 and G3 whenever necessary. Default coefficients provided in DSSAT4.5 for a medium-maturing maize cultivar were used as initial values for the calibration. Coefficients were accepted as final when simulated values closely matched the measured ones. The model was evaluated using phenology, yield, and yield component data collected from full irrigated experiments in 2013 at Bheemarayanagudi $(16.80417 \mathrm{~N}, 76.80219 \mathrm{E})$ and Ludhiana $(31.0243 \mathrm{~N}$, $75.81856 \mathrm{E})$ research stations. The agreement between simulated and measured values during calibration and evaluation was assessed using root mean square error (RMSE) and index of agreement or d-index (Willmott 1982), which are calculated using the following equations:

$$
\begin{aligned}
& \text { RMSE }=\sqrt{\frac{1}{n} \sum_{1}^{n}\left(S_{i}-O_{i}\right)^{2}} \\
& d=1-\left(\frac{\sum_{1}^{n}\left(S_{i}-O_{i}\right)^{2}}{\sum_{1}^{n}\left(\left(\left|S_{i}-\bar{O}\right|\right)+\left(\left|O_{i}-\bar{O}\right|\right)\right)^{2}}\right)
\end{aligned}
$$

where $S_{i}$ is the simulated value for the $i$ th observation, $O_{i}$ is the measured value for the $i$ th observation, $\bar{O}$ is the mean of the measured values, and $n$ is the number of observations.

Soil profile and daily climate (rainfall, maximum and minimum temperatures) data were collected from the experimental sites, while daily solar radiation data were obtained from the NASA-POWER database (NASA-POWER 2015). Data on crop management (including planting date, plant density, fertilization, and irrigation) were collected during the course of the experiments and were also collected from the regional trial database of the CIMMYT-Asia maize program at Hyderabad.

\subsection{Modeling of heat tolerance}

Temperature is one of the major environmental factors that control the rate of growth, development, and yield of crops. Since crops have specific temperature requirements to complete a given growth stage, extremely high and low temperatures that coincide with critical stages such as anthesis can have detrimental effects on crop growth, development, and yield (Luo 2011). Crops have three major cardinal temperatures: base $\left(T_{\text {base }}\right)$, a lower and upper optimum $\left(T_{\text {opt1 }}\right.$ and $\left.T_{\mathrm{opt} 2}\right)$, and maximum $\left(T_{\max }\right)$. The rate of crop development processes is a positive linear function of temperature between $T_{\text {base }}$ and $T_{\mathrm{opt} 1}$ and a negative linear function between $T_{\mathrm{opt} 2}$ and $T_{\max }$ (Roberts and Summerfield 1987). High temperature episodes close to the time of anthesis are more detrimental to the yield of many crops than the effects of the increase in mean seasonal temperature (Wheeler et al. 2000; Luo 2011). Occurrence of heat stress around silking drastically reduces kernel set in maize due to an increased abortion of kernels (Rattalino Edreira et al. 2011; Rezaei et al. 2015), while heat stress during the grain-filling period reduces kernel weight through a premature cessation of grain filling (Mayer et al. 2014). Heat tolerance in the current version of CERESMaize model is a species-wide trait described in the species file. Heat tolerance was therefore incorporated into the

\begin{tabular}{|c|c|c|c|c|c|}
\hline \multirow[t]{2}{*}{ Coefficient } & \multirow[t]{2}{*}{ Description } & \multicolumn{4}{|l|}{ Variety } \\
\hline & & $31 Y 45$ & DKC9108 & HTMH5401 & $900 \mathrm{MG}$ \\
\hline $\mathrm{P} 1$ & $\begin{array}{l}\text { Thermal time from seedling emergence to the end of the juvenile stage } \\
\text { (degree days above the base temperature of } 8^{\circ} \mathrm{C} \text { in the juvenile stage) }\end{array}$ & 320.0 & 320.0 & 300.0 & 320.0 \\
\hline $\mathrm{P} 2$ & $\begin{array}{l}\text { Photoperiod sensitivity associated with delayed growth under unfavorable } \\
\text { long-day length condition (no unit) }\end{array}$ & 0.70 & 0.70 & 0.70 & 0.70 \\
\hline P5 & $\begin{array}{l}\text { Thermal time from silking to physiological maturity (degree days above the } \\
\text { base temperature of } 8^{\circ} \mathrm{C} \text { in the maturity stage) }\end{array}$ & 980.0 & 890.0 & 995.0 & 995.0 \\
\hline $\mathrm{G} 2$ & Potential maximum number of kernels per plant & 950.0 & 950.0 & 920.0 & 798.0 \\
\hline G3 & Kernel filling rate under optimum condition $\left(\mathrm{mg} \mathrm{day}^{-1}\right)$ & 9.80 & 9.80 & 9.80 & 8.70 \\
\hline PHINT & $\begin{array}{l}\text { Interval in thermal time between successive leaf appearances } \\
\left(\text { degree days above a base temperature of } 8^{\circ} \mathrm{C} \text { ) }\right.\end{array}$ & 38.90 & 38.90 & 38.90 & 38.90 \\
\hline
\end{tabular}

Table 1 Genetic coefficients of four benchmark maize varieties determined from field experiment data 
CERES-Maize model by modifying the temperature thresholds affecting the relative grain-filling rate (RGFIL). Accordingly, heat-tolerant varieties had higher (+2) Topt2 and Tmax values than current maize varieties. This is similar to the method used by Singh et al. (2014c) in CERESsorghum.

\subsection{Estimation of climate change impacts}

The impacts of climate change on maize were determined by simulating maize growth under both the baseline and future climates. We use benchmark maize varieties that are currently grown in SA for the business-as-usual scenario, whereby the current maize varieties (or similar genetic material) will continue to be grown under the future climate. Maize is grown under both rainfed and irrigated systems in SA, and hence the impacts were determined for the two systems using the three prevailing seasons. The model was run using June planting for the rainfed systems and November and March plantings for the irrigated systems. Since projections for rainfall in SA are more uncertain than for temperature (Hijioka et al. 2014), we estimated the impact of climate change on maize productivity under two scenarios: (1) a future climate where temperatures increase but rainfall conditions remain unchanged (hereafter scenario 1) and (2) a future climate where both future temperature and rainfall conditions change according to GCM projections (hereafter scenario 2). While the first scenario allows for estimating the impacts of heat stress alone, the second one incorporates both heat and water stress effects simultaneously.

\subsubsection{Impact estimation under climate scenario 1 (heat stress only)}

The impacts under scenario 1 were determined at a representative site. Because of long-term data availability and relatively higher baseline temperature conditions, Hyderabad was selected to estimate the impact of different levels of heat stress on maize yield without changing rainfall conditions. To achieve this, yields of current maize varieties were simulated for 13 years at Hyderabad with maximum and minimum daily temperatures increasing by $1,2,3,4$, and $5^{\circ} \mathrm{C}$ from the current climate (2000-2012) to represent different levels of heating under a future climate. Simulations were run for 13 years for rainfed (June planting) and irrigated (November and March planting) systems, and the average values of the 13 years were reported for each planting season. The impacts under each temperature increase were determined relative to the simulated values under the current climate (2000-2012) conditions.

\subsubsection{Impact estimation under climate scenario 2}

The second scenario involved estimation of the impacts of climate change on maize across SA under future (2030 and
2050) climate conditions, which are projected by the GCMs selected for this study, using a spatial crop modeling approach. In order to simulate maize yield at regional level, SA was divided into square pixels (grid cells) with a square length of $5 \mathrm{arc}$ minutes $(\approx 10 \mathrm{~km}$ at the equator), and each pixel was considered as a field. The spatial allocation model (SPAM) raster map for maize (You and Wood 2006) was used to select maize-growing areas of SA using the Geographic Resources Analysis Support System (GRASS) software (http://grass.osgeo.org/).

For each grid cell, soil inputs to the model were obtained from a set of 27 generic soil profiles (HC27), developed by blending and interpreting information from both the Harmonized World Soil Database (HWSD) (FAO/IIASA/ ISRIC/ISSCAS/JRC 2008) and the WISE database (Batjes 2009) based on texture, rooting depth, and organic carbon content. Simulations were run for all soils in each grid cell, and the cell-specific output was computed from the areaweighted average based on the area share of each soil in the grid cell.

A rule-based automatic planting $(70 \%$ soil moisture within a 30 -cm soil depth, monthly maximum temperature $<50{ }^{\circ} \mathrm{C}$ and minimum temperature $>7^{\circ} \mathrm{C}$ within a 135 days planting window) was used to determine an area-specific sowing date for rainfed maize, while varieties were planted on specified dates for irrigated maize. The maize varieties were sown at 7 plants $\mathrm{m}^{-2}$, and an average of $1000 \mathrm{~kg} \mathrm{ha}^{-1}$ crop residue was used as initial residue input to the model. All varieties were simulated with three equal split applications of 200 and $300 \mathrm{~kg} \mathrm{ha}^{-1}$ nitrogen for rainfed and irrigated conditions, respectively. Details on spatial simulation of maize can be found in Tesfaye et al. (2015).

The potential impact of climate change under both scenario 1 and scenario 2 was estimated by calculating changes in maize yield between baseline and future climates as follows (Eq. 3):

$\Delta Y=\frac{\left(Y_{f i}-Y_{b}\right)}{Y_{b}}$

where $\Delta Y$ is change of yield, $Y_{f i}$ is yield under future climate $i$, and $Y_{b}$ is yield under the baseline climate.

\subsubsection{Estimation of the benefit of heat-tolerant varieties}

Like current maize varieties, heat-tolerant varieties were simulated under scenario 1 and scenario 2 climate conditions described above. Next, the benefit from heat stress tolerance was estimated by comparing the simulated yield of heattolerant maize varieties with current varieties under a given set of climate as follows (Eq. 4):

$\Delta Y=\frac{\left(Y_{v h i}-Y_{v c i}\right)}{Y_{v c i}}$ 
where $\Delta Y$ is change of yield, $Y_{v h}$ is the yield of the heattolerant maize variety under climate $i$, and $Y_{v c}$ is the yield of the current maize variety under climate $i$.

\section{Results}

\subsection{Current and future heat stress hotspots in SA}

The two GCMs predicted an annual average increase of the annual mean maximum temperature by $1.4-1.8^{\circ} \mathrm{C}$ in 2030 and by $2.1-2.6{ }^{\circ} \mathrm{C}$ in 2050 across SA. Similarly, the mean annual minimum temperature was projected to increase by $1.6-1.8{ }^{\circ} \mathrm{C}$ in 2030 and by $2.4-2.8{ }^{\circ} \mathrm{C}$ in 2050 (Fig. 1). Although the two GCMs projected increases in temperature in both 2030 and 2050 across SA, MIROC projected consistently higher increases in maximum and minimum temperatures than CSIRO across months and seasons, whereas CSIRO projected almost the same increase across seasons (Fig. 1). The projected increases in annual mean maximum and minimum temperatures by MIROC were higher than those of CSIRO by 0.42 and $0.22{ }^{\circ} \mathrm{C}$ in 2030 and 0.43 and $0.25^{\circ} \mathrm{C}$ in 2050 , respectively. In 2030 , the increase in monthly

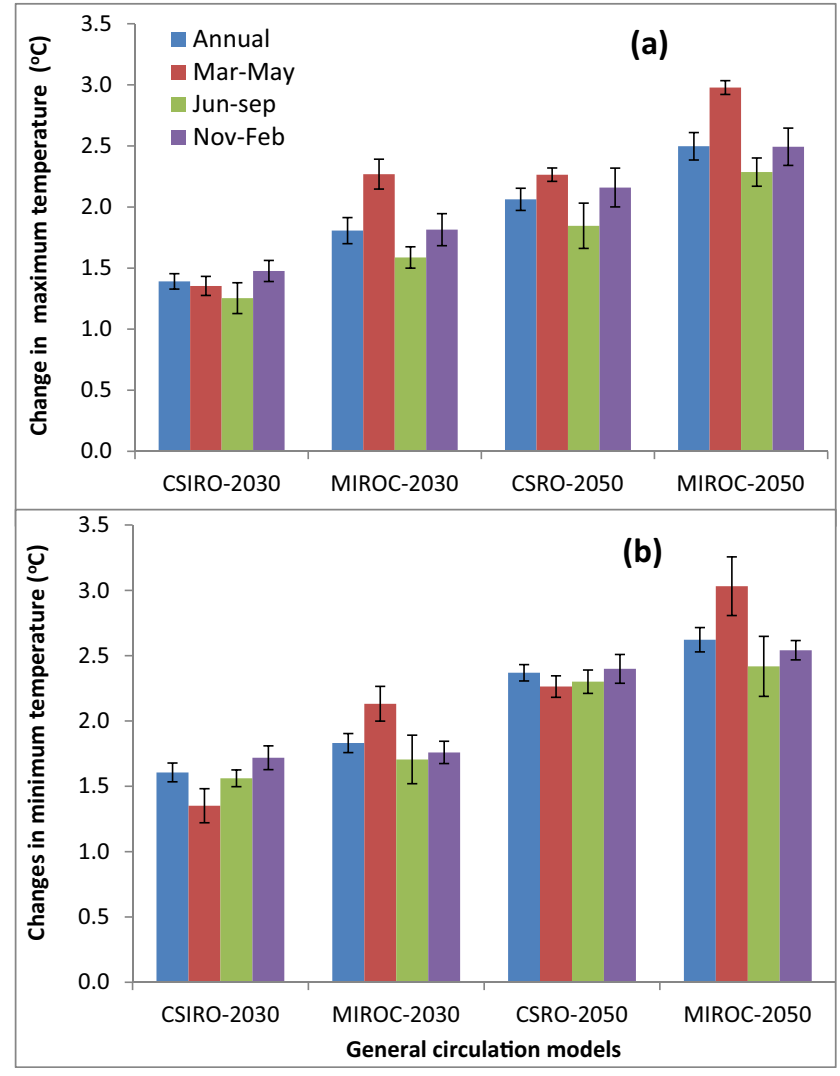

Fig. 1 Changes in annual and seasonal a maximum and $\mathbf{b}$ minimum temperatures across South Asia as projected by CSIRO and MIROC global circulation models in 2030 and 2050 relative to the baseline (2000) climate mean maximum temperature ranged from $1{ }^{\circ} \mathrm{C}$ (September, CSIRO) to $2.5{ }^{\circ} \mathrm{C}$ (May, MIROC) while that of the mean minimum temperature ranged from $1.1{ }^{\circ} \mathrm{C}$ (March, CSIRO) to $2.4{ }^{\circ} \mathrm{C}$ (May, MIROC). Similarly, the increase in mean monthly maximum temperature in 2050 ranged from $1.4{ }^{\circ} \mathrm{C}$ (September, CSIRO) to $3.1{ }^{\circ} \mathrm{C}$ (May, MIROC).

From the total physical area of about $508 \mathrm{Mha}$ in SA, about $50-60 \%$ of the area is already under heat stress $\left(>35^{\circ} \mathrm{C}\right)$ under the current climate from April to June, the premonsoon hot season (Fig. 2a). During the monsoon, the heat stress under the current climate subsides from $23 \%$ of the total area in July to $8 \%$ in October (Fig. 2a). Mean maximum temperatures remain below the maximum limit of maize under the baseline climate in the post-monsoon cool season (November to February) across all areas in SA.

The heat stress affected area in SA will increase under the future climate, particularly in the pre-monsoon and monsoon season (Fig. 2b). Relative to the baseline, the increase in heat-stressed areas ranged from $3 \%$ (February) to $12 \%$ (March) in 2030, and $3 \%$ (February) to $21 \%$ (March) in 2050 (Fig. 2b). While March to October will be the period for future increases in heatstressed areas, the month of March will see the highest increase in both 2030 and 2050 (Fig. 2b).

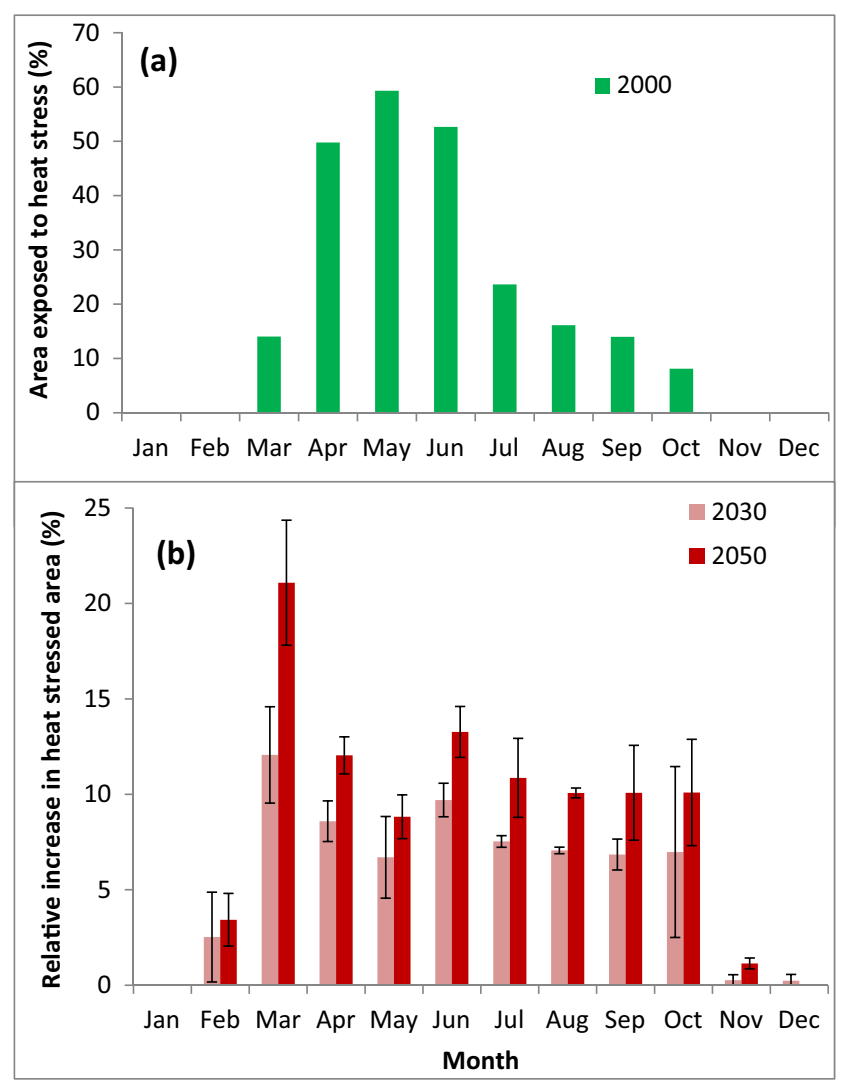

Fig. 2 Proportion of a area from total physical area exposed to heat stress under current climate in each month and $\mathbf{b}$ relative monthly increase in heat stressed area under future climate in South Asia 


\subsection{Model calibration and evaluation}

A comparison of measured and simulated days to anthesis and maturity of the four varieties, for both the calibration and evaluation dataset, showed good agreement between the measured and simulated values, indicating that the benchmark varieties were accurately represented by the calibrated genetic coefficients shown in Table 1. For the combined calibration and evaluation dataset, RMSE averaged 3.8 days for anthesis and 6.6 days for maturity with a d-index value of 0.85 and 0.76 , respectively. The average simulated yield of the benchmark varieties across all site seasons was closely related to the measured grain yield. The RMSE and d-index values for the combined calibration and evaluation yield data were $1.2 \mathrm{t} \mathrm{ha}^{-1}$ and 0.91 , respectively.

\subsection{Impact of climate change on maize yield}

\subsubsection{Impact under climate scenario 1}

A $1{ }^{\circ} \mathrm{C}$ increase in maximum and minimum temperature above the current climate (2000-2012) at Hyderabad already has a detrimental effect on the modeled yield of current maize varieties - with modeled yields declining further with incremental temperatures and the degree of the impact varying by season (Fig. 3). Among planting seasons, the impact of heat stress on the yield of current maize varieties was the highest in the already heat stressed March-May season, while it was lower in the monsoon (June-September) season. Relative to the baseline climate, an increase in maximum and minimum temperatures by $1{ }^{\circ} \mathrm{C}$ caused a yield reduction of 55,13 , and $32 \%$, while an increase by $5{ }^{\circ} \mathrm{C}$ caused a reduction of 98,64 , and $75 \%$ in the March, June, and November planting seasons, respectively (Fig. 3).

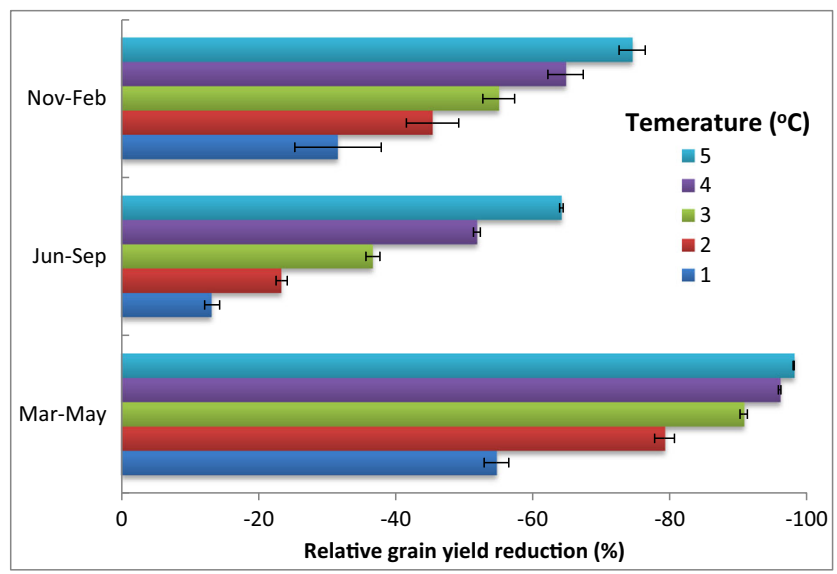

Fig. 3 Impact of increased temperature levels (under baseline rainfall and irrigation conditions) on the grain yield of maize varieties currently grown in South Asia

\subsubsection{Impact under climate scenario 2}

Yield reductions due to climate change were generally higher under the MIROC than under the CSIRO GCM projections in both 2030 and 2050 for both rainfed and irrigated systems (Figs. 4 and 5). Under rainfed conditions, climate change is likely to reduce maize yield across SA by an average of 3.3$6.4 \%$ in 2030 and 5.2-12.2\% in 2050 if current varieties were grown under future climate conditions. In 2030, most areas in SA may experience a yield reduction of 5-15\%, while some pockets in southern and eastern India and in Bangladesh may see a yield increase (Fig. 4). In 2050, however, a large part of SA may experience a yield reduction of $15-25 \%$, and considerable part of the region may see a reduction of above $25 \%$, particularly under the MIROC GCM projection (Fig. 5). The areas with severe yield reduction are scattered across northern, eastern, and southern India, including the southern part of Nepal (Fig. 5).

SA may also experience an irrigated yield reduction of $3.0 \%$ (CSIRO) to $8.2 \%$ (MIROC) in 2030 and $5.4 \%$ (CSIRO) to $13.8 \%$ (MIROC) in 2050. Although scattered all over the region, the areas that experience the highest irrigated maize yield reduction are located in the irrigated areas of Afghanistan, Pakistan, and eastern India (Figs. 4 and 5).

\subsection{Role of heat-tolerant maize varieties in reducing the impact of climate change}

Heat-tolerant maize varieties showed good potential for minimizing the impact of heat stress on grain yield under climate scenario 1 (Fig. 6). Depending on the level of temperature increase above the current levels, heat-tolerant varieties gave a yield advantage of 5-27, 1-10, and 6-8\% in the March, June, and November planting seasons, respectively, relative to the current maize varieties. Because of existing differences in the degree of heat stress among the growing seasons, the advantage from heat-tolerant varieties in reducing yield loss from heat stress varied with temperature levels. For example, the advantage of growing heat-tolerant varieties decreases with an increase in heat stress level in the March planting season, whereas it increases with temperature increase in the June planting season (Fig. 6). On the other hand, the benefit from heat-tolerant varieties remained almost the same across increasing temperature levels in the November planting season, suggesting that future temperature increases during this season may not have a significant heat stress effect on maize yield.

Compared to current varieties on a regional scale, heattolerant varieties minimized yield reduction due to climate change (climate scenario 2) by up to $36 \%$ under rainfed and $93 \%$ under irrigated conditions in 2030 and by up to 33 and $86 \%$ in 2050, respectively. According to the GCM projection, the spatial average yield benefit of heat-tolerant varieties over 


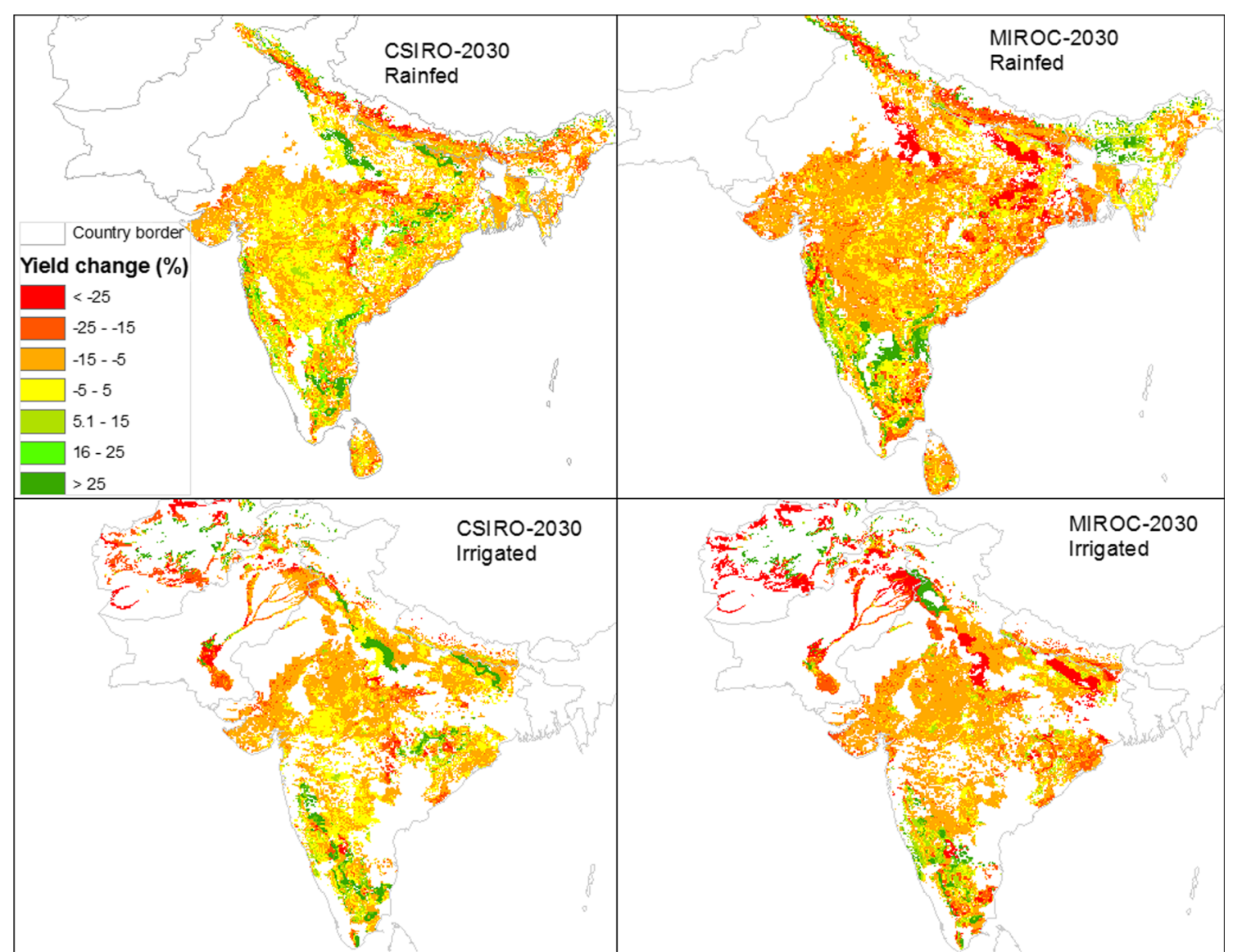

Fig. 4 Impact of climate change on rainfed (upper panel) and irrigated (lower panel) maize across South Asia in 2030 using CSIRO (left panel) and MIROC (right panel) climate projections

that of current varieties ranged from 18 to $28 \%$ and 18 to $19 \%$ in 2030 and from 16 to $18 \%$ and 16 to $21 \%$ in 2050 under rainfed and irrigated conditions, respectively. Higher $(>20 \%)$ yield benefits of rainfed heat-tolerant varieties occurred in most areas of India in 2030 and 2050 except in the central part (Figs. 7 and 8). Similarly, the highest yield benefit of irrigated heat-tolerant varieties was found in most irrigated areas of Afghanistan and Pakistan and in large parts of India except the central part (Figs. 7 and 8).

\section{Discussion}

Climate change will adversely affect food security in SA (Schmidhuber and Tubiello 2007) and there is an urgent need to develop technologies that adapt to the changing climate. Climate change, coupled with increased cultivation of maize in the warmer seasons and environments, will further exacerbate the detrimental impacts of heat stress on maize productivity in SA (Prasanna 2011). Therefore, developing and deploying climate-resilient germplasm has become one of the topmost priorities in the tropical/sub-tropical maizegrowing regions (Cairns et al. 2012). For example, various sources of heat-tolerance traits have been identified in the maize germplasm accessions of CIMMYT for breeding new varieties in SA and sub-Saharan Africa that are high yielding as well as having improved drought and heat tolerance. However, an early assessment of the potential benefits of new technologies would be useful before significant investments are made. This study assessed the potential impact of climate change on maize production in SA in 2030 and 2050 under two scenarios: (1) a business-as-usual scenario where current maize varieties or similar genetic material are grown under future climate conditions, and (2) an adaptation scenario where current maize varieties are replaced with heat-tolerant maize varieties in the future.

Similar to previous studies (e.g., Ahmed and Suphachalasai 2014; Chauhan et al. 2014; Lal 2011, 2005) that reported future temperature increases in the different parts of SA, the GCMs used in this study projected an increase in mean maximum and minimum temperatures across SA in 2030 and 2050. The annual mean maximum and minimum temperature increases will remain below $2{ }^{\circ} \mathrm{C}$ by 2030 but will exceed $2{ }^{\circ} \mathrm{C}$ by 2050 under the RCP 6.0 scenario used in this study. The temperature projections were generally higher for the MIROC than for the CSIRO GCM. This could be due to the fact that 


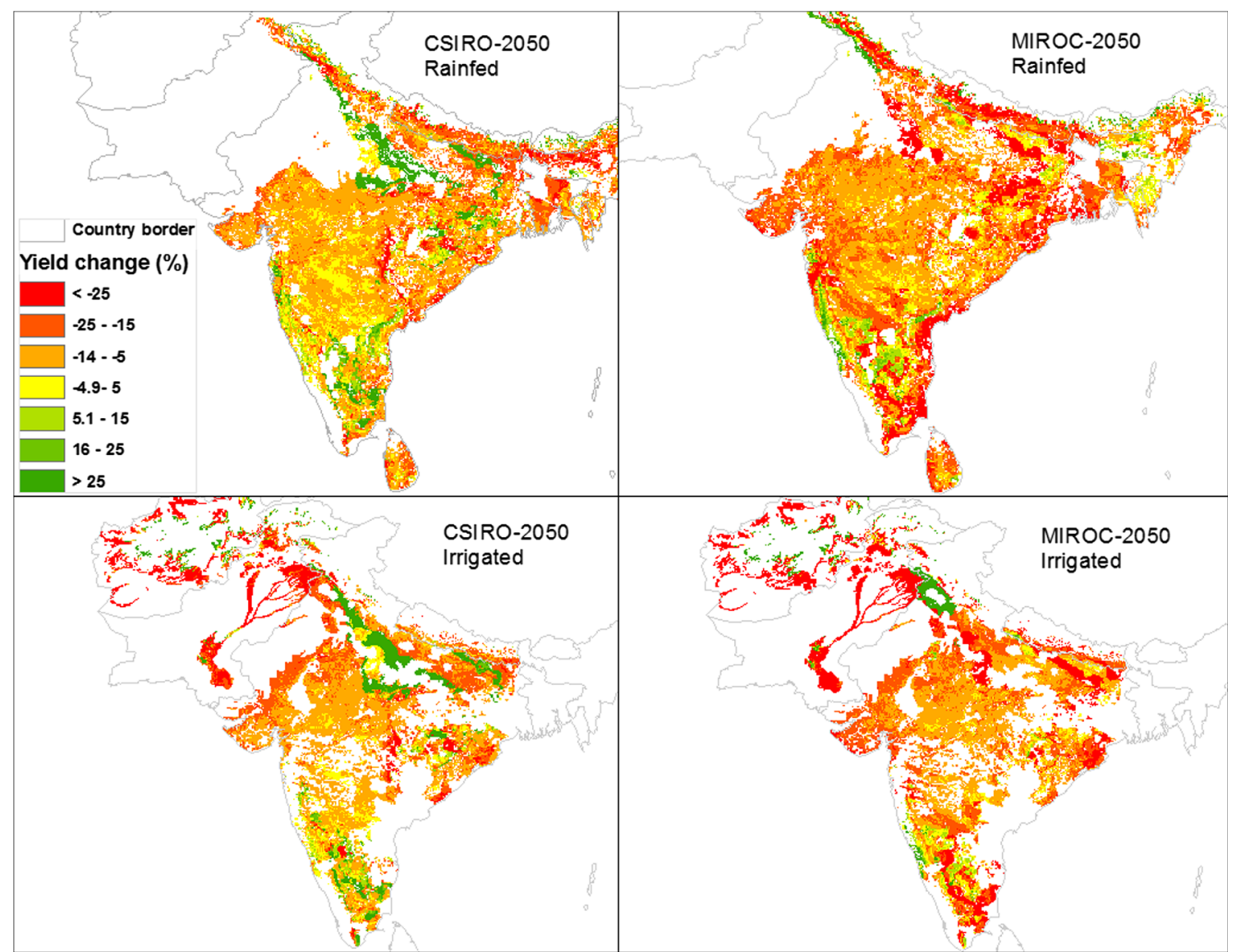

Fig. 5 Impact of climate change on rainfed (upper panel) and irrigated (lower panel) maize across South Asia in 2050 using CSIRO (left panel) and MIROC (right panel) climate projections

the version of MIROC used in this study (MIROC-ESMCHEM) included a robust atmospheric chemistry component which was found to reproduce past records reasonably well (Watanabe et al. 2011).

The future increase in temperatures and associated heat stress levels for maize varies across seasons, locations, and time periods. A large proportion of the total area in SA has

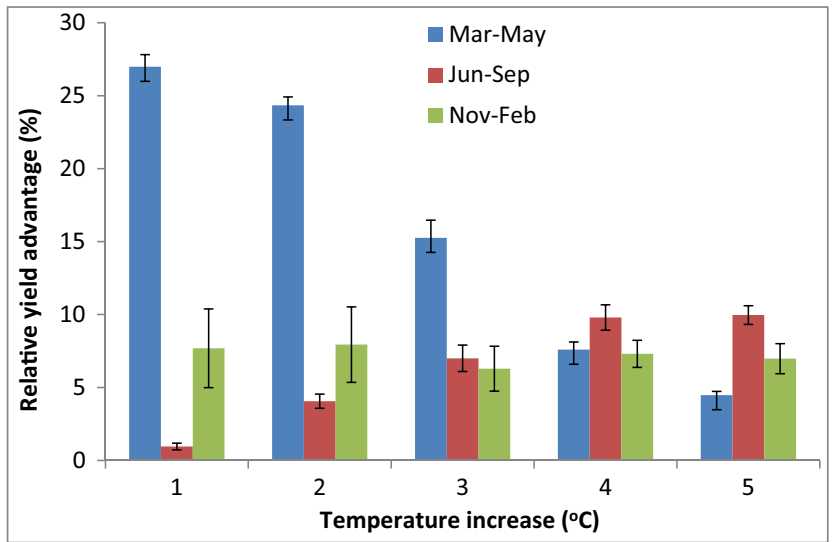

Fig. 6 Relative yield advantage of heat-tolerant varieties over that of current maize varieties under different levels of heat stress already been under heat stress $\left(>35^{\circ} \mathrm{C}\right)$, particularly between April and June (Fig. 2), and this is projected to increase by 7 $12 \%$ in 2030 and by $10-21 \%$ by 2050 (Fig. 3). Maize is grown three times per year in many parts of SA, and this exposes the crop to different levels of heat stress, particularly for spring (pre-monsoon) maize which has become an important option for intensifying and diversifying cropping systems in SA, especially in the upper and middle Indo-Gangetic Plains (Prasanna 2011). The highest current and future heat stress levels occur in the March-May season when existing temperature levels are already stressful for maize, followed by the June-September season. On the other hand, both current and future heat stress levels are relatively lower for the October-February period, as temperatures remain within the maximum threshold for maize growing during this period, thus making it a preferred season for growing relatively heat-sensitive maize varieties, as compared to the MarchMay season.

Crop simulation models have been used to forecast crop growth and yield advantages due to new technologies in different target environments. The models provide a means to modify cultivar traits within the observed limits of their genetic variability and to assess the potential benefit of 


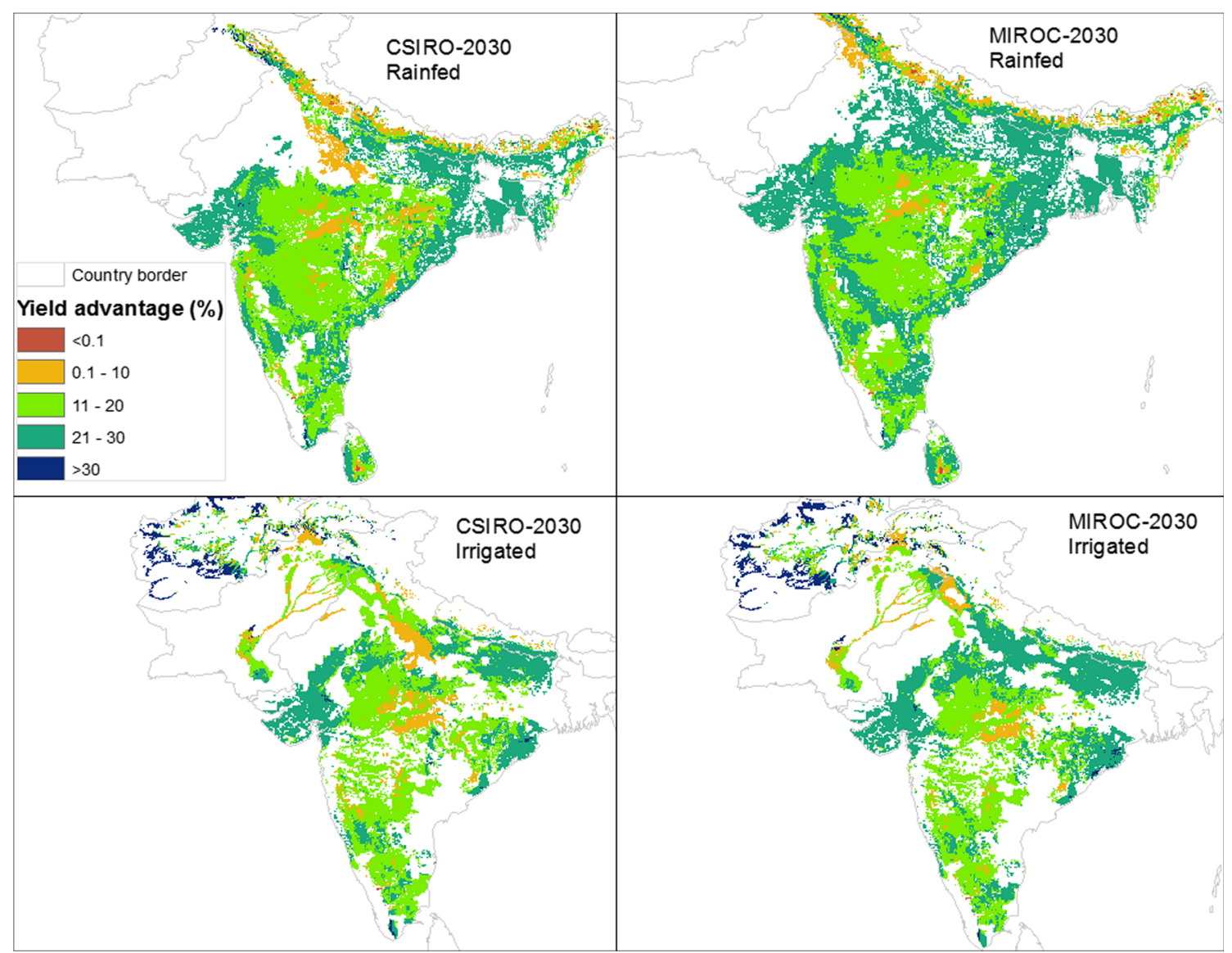

Fig. 7 Yield advantage of heat-tolerant varieties over that of current maize varieties in 2030 under rainfed (upper panel) and irrigated (lower panel) conditions across South Asia using CSIRO (left panel) and MIROC (right panel) climate projections

incorporating such traits singly or in multiple combinations for the target environment (Boote et al. 2001; Singh et al. 2012). However, models need to be calibrated and evaluated for the target environment before they are applied. The efforts made to calibrate and evaluate the CERES-Maize model in the current study indicate that the benchmark varieties were accurately represented by the calibrated genetic coefficients and that the CERES-Maize model has captured the response of the maize varieties across environments.

Simulation of maize yield under increasing temperature levels while maintaining baseline rainfall conditions at Hyderabad indicates that yield decreases with an increase in temperature in all planting seasons. However, yield was generally higher in the November planting season by at least twofold and sixfold across temperature levels $\left(0-5{ }^{\circ} \mathrm{C}\right) \mathrm{com}$ pared to the June and March planting seasons, respectively. For example, the average simulated maize yields were 1.2, 2.6, and $6.9 \mathrm{t} \mathrm{ha}^{-1}$ under the baseline climate, and 0.5, 2.0, and $3.7 \mathrm{tha}^{-1}$ under the $+2{ }^{\circ} \mathrm{C}$ warmer climate for the March, June, and November plantings, respectively. The three planting seasons have unique temperature distributions: in the March planting season, temperatures are relatively lower during the planting and vegetative growth stages but increase during the anthesis and reproductive growth stages of maize; in the June planting season, temperatures are relatively higher during the planting and vegetative growth stages (June-July) but decrease as the maize plants progress toward the anthesis and reproductive growth phases (August-September); and in the November planting, temperatures are generally lower than the other two seasons with a seasonal distribution of somewhat higher values during planting (November) and lower ones afterward (December-February).

Extreme heat stress during the crop reproductive period is more critical for crop productivity than the mean seasonal temperature (Luo 2011; Deryng et al. 2014). Several studies have found that temperatures of above $35{ }^{\circ} \mathrm{C}$ are damaging to several processes including maize pollen viability (Herrero and Johnson 1980; Schoper et al. 1987; Dupuis and Dumas 1990), kernel growth rate (potential), and final kernel size (Jones et al. 1984) as well as grain sink strength and yield (Commuri and Jones 2001). This, therefore, explains why the largest relative yield reduction occurred in the March-May season and the lowest in the June-September season in the current study despite similar seasonal mean temperature levels in the two seasons. 


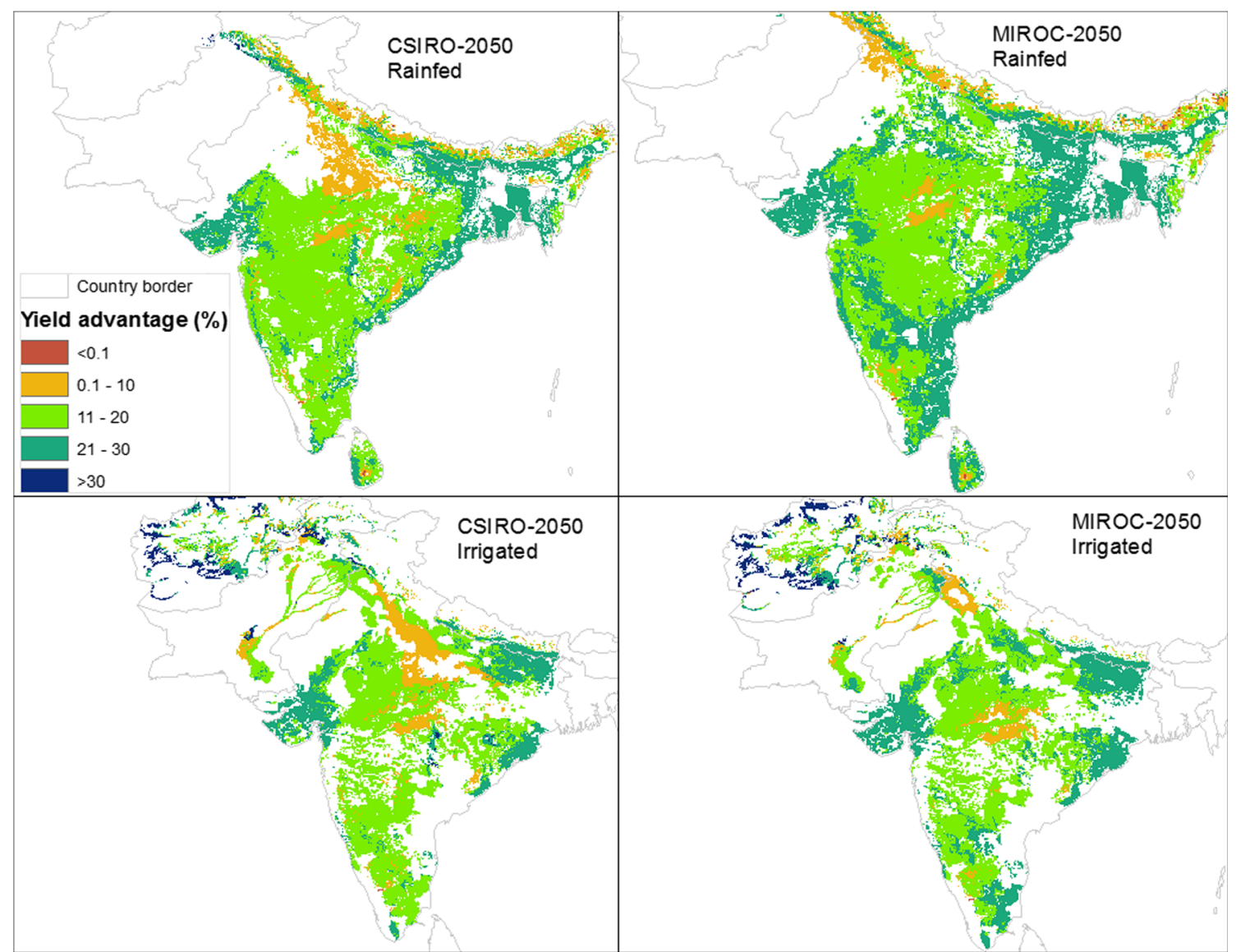

Fig. 8 Yield advantage of heat-tolerant varieties over that of current maize varieties in 2050 under rainfed (upper panel) and irrigated (lower panel) conditions across South Asia using CSIRO (left panel) and MIROC (right panel) climate projections

Simulation of the yield of current maize varieties under future temperature and rainfall conditions at a regional scale in 2030 and 2050 indicates that maize will be affected by climate change across SA and that the impact will vary both spatially and temporally. Although some pockets in southern and eastern India and Bangladesh may see yield increases, most areas in SA are likely to experience an average yield reduction of up to $15 \%$ in 2030 and $25 \%$ in 2050 (Figs. 5 and 6). This is in line with previous findings that indicate that maize is a crop that faces progressively worse impacts under a range of RCPs by the 2080s than spring wheat or soybean at a global scale (Deryng et al. 2014). The authors find that extreme heat stress at anthesis by the 2080s (relative to the 1980s), under RCP 8.5 with $\mathrm{CO}_{2}$ fertilization effects, could double global losses of maize yield and that strong heat stress at anthesis would be responsible for up to $45 \%$ of global average maize yield losses. Another impact of high temperature is the acceleration of the phenological cycle which usually limits the period required for normal growth and development of crops. For example, acceleration of the phenological cycle due to projected (2050) high temperature resulted in the reduction of groundnut yield in the southern part of India (Kadiyala et al. 2015).
In as much as the impacts of climate change on maize are quantified effectively using simulation models, such models can also be used to study the implications of adaptation options. In this study, we used crop models to assess the potential of heat-tolerant maize varieties as one of the options for adapting maize to the changing climate conditions in SA. The results clearly indicate the potential of heat-tolerant varieties in minimizing the maize yield losses expected under climate change in SA. In already heat-stressed areas such as Hyderabad, heat-tolerant maize varieties could still minimize yield losses under future climate conditions, although the effect varies with the degree of future temperature increase and with planting season. The regional simulations indicated that by improving heat tolerance alone, it is possible to reduce maize yield loss by up to 36 and $33 \%$ under rainfed conditions and by 93 and $86 \%$ under irrigated conditions in 2030 and 2050, respectively. However, the wide range of impacts across SA underscores the need for carefully targeted adaptation responses. It also underlines the need to complement breeding with other innovations as heat stress tolerant varieties alone would not be sufficient to cope with climate change. The advantages of heattolerant varieties were found to be more pronounced under irrigated conditions compared to rainfed, in part associated with the 
divergent seasonality and associated temperature stress. Still, it is also important to consider other factors such as drought in adapting maize to the changing climate in the region. For example, models have shown that incorporating both drought and heat tolerance traits have resulted in an increase in the yield of sorghum (Singh et al. 2014c), groundnuts (Singh et al. 2014b), and chickpeas (Singh et al. 2014a) in several environments.

Our study involved some important assumptions and uncertainties. Firstly, CERES-Maize does not include crop pest and disease losses, and hence these factors are assumed to be well controlled. Secondly, our study focused only on heat stress tolerance during the reproductive stage of maize and does not consider other breeding or agronomic adaptation options, for the sake of focusing on the unequivocal component of climate change - temperature increase. Thirdly, the study assumed that water remains available in irrigated cropland which may not be realistic under future climate conditions. Fourthly, the effect of $\mathrm{CO}_{2}$ fertilization on maize yield is not included mainly because maize is a $\mathrm{C} 4$ plant where the potential for $\mathrm{CO}_{2}$ fertilization effects remain unclear and uncertainties related to model sensitivity to $\mathrm{CO}_{2}$ fertilization (Challinor et al. 2009; Ruane et al. 2011). Finally, our study used two GCMs and one crop model and therefore may have omitted a source of model uncertainties. This indicates scope for future studies on the response of maize to climate change in SA.

\section{Conclusion}

This study quantifies the impact of climate change on maize production in SA and the benefit from growing heat stress tolerant varieties under different climate change scenarios. The results showed spatial and temporal disparities in the impacts of climate change within SA and underscored the need for carefully targeted adaptation responses including breeding for greater crop heat stress tolerance. Incorporating heat tolerance traits into maize varieties showed great promise for adapting maize to the changing climate. This study thereby helps researchers and decision makers understand the extent of climate change and its potential impacts to identify and target vulnerable areas and to analyze benefits from investing in heat stress tolerant maize research for development.

In addition, the results of this study have important implications for the current efforts to diversify cropping systems in SA. For instance, maize is seen as an option to diversify the intensive wheat-rice cropping systems in the Indo-Gangetic plains, but the potential of maize varies by cropping season. Therefore, it is important to identify the combinations of growing regions and seasons for which these diversification efforts would be the most promising, in order to lead to a sustainable increase in crop production in the region. Thus, beyond the recent study, it is necessary to assess the potential for keeping maize production at the current level and to be able to further increase it to meet the growing demand for maize, especially in those regions under rainfed conditions where farmers currently grow varieties that are not tolerant to heat stress. This requires a more in-depth analysis of specific maize-growing environments, current varieties adopted, and future demand for maize grain in terms of quantity, quality, and types of grain.

Acknowledgments This work was supported by the CGIAR Program on Policies, Markets, and Institutions (PIM) led by the International Food Policy Research Institute (IFPRI) through Global Futures and Strategic Foresight (GFSF) project funded by the Bill \& Melinda Gates Foundation, the Heat Tolerance Maize for Asia (HTMA) project funded by the US Agency for International Development (USAID) under the Feed-the-Future initiative of the US government, and the CGIAR Research Programs on Climate Change, Agriculture and Food Security (CCAFS). The boundaries and names shown and the designations used on all maps do not imply official endorsement or acceptance by the authors. The views expressed here are those of the authors and do not necessarily reflect the views of authors' institutions or donors.

Open Access This article is distributed under the terms of the Creative Commons Attribution 4.0 International License (http:// creativecommons.org/licenses/by/4.0/), which permits unrestricted use, distribution, and reproduction in any medium, provided you give appropriate credit to the original author(s) and the source, provide a link to the Creative Commons license, and indicate if changes were made.

\section{References}

Ahmed M, Suphachalasai S (2014) Assessing the costs of climate change and adaptation in South Asia. Asian Development Bank, Mandaluyong, Philippines

Batjes NH (2009) Harmonized soil profile data for applications at global and continental scales: updates to the WISE database. Soil Use Manag 25:124-127. doi:10.1111/j.1475-2743.2009.00202.x

Boote KJ, Kropff MJ, Bindraban PS (2001) Physiology and modelling of traits in crop plants: implications for genetic improvement. Agric Syst 70:395-420. doi:10.1016/S0308-521X(01)00053-1

Cairns JE, Sonder K, Zaidi PH, et al. (2012) Maize production in a changing climate: impacts, adaptation, and mitigation strategies. Adv Agron 114:1-57. doi:10.1016/B978-0-12-394275-3.00006-7

CCAFS (2014) Climate data portal. Climate Change, Agriculture and Food Security, Geneva, Swizerland. http://www.ccafs-climate. org/data/. Accessed 10 Apr 2014

Challinor AJ, Ewert F, Arnold S, et al. (2009) Crops and climate change: progress, trends, and challenges in simulating impacts and informing adaptation. J Exp Bot 60:2775-2789. doi:10.1093/jxb/erp062

Chauhan BS, Prabhjyot-Kaur, Mahajan G, et al. (2014) Global warming and its possible impact on agriculture in India. Adv Agron 123:65121. doi:10.1016/B978-0-12-420225-2.00002-9

Commuri PD, Jones RD (2001) High temperatures during endosperm cell division in maize: a genotypic comparison under in vitro and field conditions. Crop Sci 41:1122-1130

Deryng D, Conway D, Ramankutty N, et al. (2014) Global crop yield response to extreme heat stress under multiple climate change futures. Environ Res Lett 9:034011. doi:10.1088/1748-9326/9/3/034011

Dupuis L, Dumas C (1990) Influence of temperature stress on in vitro fertilization and heat shock protein synthesis in maize (Zea mays L.) reproductive systems. Plant Physiol 94:665-670 
FAO (2008) Climate change and food security: a framework document. Rome, Italy

FAO/IIASA/ISRIC/ISSCAS/JRC (2008) Harmonized World Soil Database (version 1.0). FAO and IIASA, FAO, Rome and IIASA, Laxenburg, Austria

FAOSTAT (2013) FAO statistical databases. Food and Agriculture Organization of the United Nations Statistics Division

Gourdji SM, Sibley AM, Lobell DB (2013) Global crop exposure to critical high temperatures in the reproductive period: historical trends and future projections. Environ Res Lett 8:024041. doi:10.1088/1748-9326/8/2/024041

Hellin J, Krishna VV, Erenstein O, Boeber C (2015) India's poultry revolution: implications for its sustenance and the global poultry trade. International Food and Agribusiness Management Review 18:151-164

Herrero MP, Johnson RR (1980) High temperature stress and pollen viability in maize. Crop Sci 20:796-800

Hijioka Y, Lin E, Pereira JJ, et al. (2014) Asia. In: Barros VR, Field CB, Dokken DJ, et al (eds) Clim. Chang. 2014 Impacts, Adapt. Vulnerability. Part B Reg. Asp. Contrib. Work. Gr. II to Fifth Assess. Rep. Intergov. Panel Clim. Chang. Cambridge University Press, Cambridge, UK and New York, USA, p 1327-1370

Hijmans RJ, Cameron SE, Parra JL, et al. (2005) Very high resolution interpolated climate surfaces for global land areas. Int J Climatol 25: 1965-1978. doi:10.1002/joc. 1276

Hoogenboom G, Jones F, Wilkens P, et al. (2010) Decision support system for agrotechnology transfer version 4.5 [CD-ROM]

Jones CA, Kiniry JR (1986) CERES-maize: a simulation model of maize growth and development. Texas A\&M University Press, Texas

Jones RJ, Ouattar S, Crookston RK (1984) Thermal environment during endosperm cell division and grain filling in maize: effects on kernel growth and development in vitro. Crop Sci 24:133-137

Jones JW, Hoogenboom G, Porter CH, et al. (2003) The DSSAT cropping system model. Eur J Agron 18:235-265. doi:10.1016/S1161-0301 (02)00107-7

Kadiyala MDM, Nedumaran S, Singh P, et al. (2015) An integrated crop model and GIS decision support system for assisting agronomic decision making under climate change. Sci Total Environ 521-522: 123-134. doi:10.1016/j.scitotenv.2015.03.097

Knox J, Hess T, Daccache A, Wheeler T (2012) Climate change impacts on crop productivity in Africa and South Asia. Environ Res Lett 7: 034032. doi:10.1088/1748-9326/7/3/034032

Lal M (2005) Climate change-implications for India's water resources. In: Mirza MMQ, Ahmad QK (eds) Clim. Chang. Water Resour. South Asia. A.A. Balkema Publishers (Taylor \& Francis Group), Lieden, The Netherlands, p 155-193

Lal M (2011) Implications of climate change in sustained agricultural productivity in South Asia. Reg Environ Chang 11:79-94. doi:10.1007/s10113-010-0166-9

Lobell DB, Bänziger M, Magorokosho C, Vivek B (2011a) Nonlinear heat effects on African maize as evidenced by historical yield trials. Nat Clim Chang 1:42-45. doi:10.1038/nclimate1043

Lobell DB, Schlenker W, Costa-Roberts J (2011b) Climate trends and global crop production since 1980. Science 333:616-620. doi:10.1126/science.1204531

Luo Q (2011) Temperature thresholds and crop production: a review. Clim Chang 109:583-598. doi:10.1007/s10584-011-0028-6

Mayer LI, Rattalino Edreira JI, Maddonni GA (2014) Oil yield components of maize crops exposed to heat stress during early and late grain-filling stages. Crop Sci 54:2236. doi:10.2135/cropsci2013.11.0795

NASA-POWER (2015) Climatology resource for agroclimatology. http://power.larc.nasa.gov/cgi-bin/agro.cgi?email=agroclim@larc. nasa.gov. Accessed 13 Apr 2015

Prasanna BM (2011) Maize in the developing world: trends, challenges, and opportunities. In: Zaidi PH, Cairns JE (eds) Addressing Clim. Chang. Eff. Meet. Maize Demand Asia - B. Ext. Summ. 11th Asian Maz. Conf. Nanning, China, pp 26-38
Rattalino Edreira JI, Budakli Carpici E, Sammarro D, Otegui ME (2011) Heat stress effects around flowering on kernel set of temperate and tropical maize hybrids. F Crop Res 123:62-73. doi:10.1016/j. fcr.2011.04.015

Rezaei EE, Webber H, Gaiser T, et al. (2015) Heat stress in cereals: mechanisms and modelling. Eur J Agron 64:98-113. doi:10.1016 j.eja.2014.10.003

Rinaldi M, Ventrella D, Gagliano C (2007) Comparison of nitrogen and irrigation strategies in tomato using CROPGRO model. Agric Water Manag 87:91-105

Roberts EH, Summerfield R (1987) Measurement and prediction of flowering in annual crops. In: Atherton JG (ed) Manipulation of flowering. Elsevier Ltd., London, pp. 17-50

Ruane AC, Cecil LD, Horton RM, et al. (2011) Climate change impact uncertainties for maize in Panama: farm information, climate projections, and yield sensitivities. Agric For Meteorol 170:132-145. doi:10.1016/j.agrformet.2011.10.015

Schmidhuber J, Tubiello FN (2007) Global food security under climate change. Proc Natl Acad Sci U S A 104:19703-19708. doi:10.1073 /pnas.0701976104

Schoper JB, Lambert RJ, Vasilas BL, Westgate M (1987) Plant factors controlling seed set in maize. Plant Physiol 81:121-125

Shiferaw B, Prasanna BM, Hellin J, Bänziger M (2011) Crops that feed the world 6. Past successes and future challenges to the role played by maize in global food security. Food Secur 3:307-327. doi:10.1007/s12571-011-0140-5

Singh P, Boote KJ, Kumar U, et al. (2012) Evaluation of genetic traits for improving productivity and adaptation of groundnut to climate change in India. J Agron Crop Sci 198:399-413. doi:10.1111 j.1439-037X.2012.00522.x

Singh P, Nedumaran S, Boote KJ, et al. (2014a) Climate change impacts and potential benefits of drought and heat tolerance in chickpea in South Asia and East Africa. Eur J Agron 52:123-137. doi:10.1016/j. eja.2013.09.018

Singh P, Nedumaran S, Ntare BR, et al. (2014b) Potential benefits of drought and heat tolerance in groundnut for adaptation to climate change in India and West Africa. Mitig Adapt Strateg Glob Chang 19:509-529. doi:10.1007/s11027-012-9446-7

Singh P, Nedumaran S, Traore PCS, et al. (2014c) Quantifying potential benefits of drought and heat tolerance in rainy season sorghum for adapting to climate change. Agric For Meteorol 185:37-48. doi:10.1016/j.agrformet.2013.10.012

Swaminathan MS, Kesavan PC (2012) Agricultural research in an era of climate change. Agric Res 1:3-11. doi:10.1007/s40003-011-0009-Z

Tesfaye K, Gbegbelegbe S, Cairns JE, et al. (2015) Maize systems under climate change in sub-Saharan Africa. Int J Clim Chang Strateg Manag 7:247-271. doi:10.1108/IJCCSM-01-2014-0005

van Vuuren DP, Carter TR (2014) Climate and socio-economic scenarios for climate change research and assessment: reconciling the new with the ol. Clim Chang 122:415-429. doi:10.1007/s10584-013-0974-2

van Vuuren DP, Edmonds J, Kainuma M, et al. (2011) The representative concentration pathways: an overview. Clim Chang 109:5-31. doi:10.1007/s10584-011-0148-z

Watanabe S, Hajima T, Sudo K, et al. (2011) MIROC-ESM: model description and basic results of CMIP5-20c3m experiments. Geosci Model Dev Discuss 4:1063-1128. doi:10.5194/gmdd-4-1063-2011

Wheeler TR, Craufurd PQ, Ellis RH, et al. (2000) Temperature variability and the yield of annual crops. Agric Ecosyst Environ 82:159-167

Willmott CJ (1982) Some comments on the evaluation of model performance. Bull Am Meteorol Soc 63:1309-1313. doi:10.1175/1520 0477(1982)063<1309:SCOTEO > 2.0.CO;2

You L, Wood SR (2006) An entropy approach to spatial disaggregation of agricultural production. Agric Syst 90:329-347. doi:10.1016/j. agsy.2006.01.008 